\title{
The Assessment of Determinants of Credit Services' Choices among Students
}

\begin{abstract}
The article analyses demographic factors which determine the students' intention to borrow and to choose a particular credit service, i.e., what characteristics of credit services are the most important for students when making a choice of a particular credit service.
\end{abstract}

Keywords: personal finance, borrowing decisions, lending services.

Straipsnyje analizuojama, kokie demografiniai veiksniai lemia studentų ketinimą skolintis ir rinktis konkrečią kreditavimo paslaugą, t.y. kokios kreditavimo paslaugų charakteristikos yra svarbiausios studentams priimant sprendimą, kokią kreditavimo paslaugą pasirinkti.

Raktiniai žodžiai: asmeniniai finansai, skolinimosi sprendimai, kreditavimo rinka.

\section{Introduction}

Over the last decade, credit services market, similar to the entire financial system, is affected and reshaped due to rapid development of technological innovations and changing patterns of consumer behaviour. The changes are observed not only in the form and content of the services provided by traditional credit institutions, i.e., banks, which are increasingly expanding their online and mobile banking services. New types of credit providers offering innovative lending services via new and existing channels are adding to the market and affordable alternative borrowing options become much more easily available to the consumers. As noted by
J. A. Ketterer (2017), today's customers are so accustomed to digital space (using Google, Amazon, Facebook, eBay), that they expect such experience to be met on the financial services marke tas well. On the other hand, alternative credit services providers also play an important role in the credit market by reshaping the attitude of the customers towards borrowing process and time altering demand for such services (Drummer et al., 2016). Uncertainty dynamically affecting credit market both from the suppliers' side and by the financial behavior of credit users, raises questions on how traditional credit providers respond to the new credit market models and increasing competitiveness of this market, and how consumer

Gintare BARTKEVIČIŪTE் - MBA from Vytautas Magnus University, graduate student of the Faculty of Economics and Management. Address: S. Daukanto str. 28, Kaunas, Lithuania. E-mail: gintare.bartkeviciute@vdu.lt

Asta GAIGALIENE - PhD, associate professor at Finance Department, Faculty of Economics and Management, Vytautas Magnus University, Lithuania. Address: S. Daukanto str. 28, LT-44248, Kaunas, Lithuania. Phone: +370 37 327856. E-mail: asta.gaigaliene@vdu.lt

Renata LEGENZOVA - PhD, associate professor, head of Finance Department, Faculty of Economics and Management, Vytautas Magnus University, Lithuania. Address: S. Daukanto str. 28, LT-44248, Kaunas, Lithuania. Phone: +370 37 327856. E-mail: renata.legenzova@vdu.lt 
preferences and needs are changing along with the changes of credit market and its environment. This article concentrates on understanding the changes in the consumer side of the credit market. Such analysis is relevant to various credit providers, as it allows an assessment of the criteria on which individuals choose a credit provider, what services they choose and how such knowledge would allow credit providers to increase their competitive advantage.

Credit services related problems are widely analyzed in the scientific literature from the point of view of both credit providers and consumers. In Lithuania, research related to the behaviour of the credit market participants is limited and fragemented (Žukauskas, Žukauskienè, 2012; Račkauskas, Liesionis, 2013; Ališauskaitè-Šeškienè et al., 2015; Gasparenienè et al., 2015) and no research related to the providers of the alternative credit services has been identified. Literature analysis revealed that a number of previous research is concentrated on the actual use or intention to use a particular credit service rather than a general intention to borrow. For example, earlier research examined intention to use credit cards (Kennedy, 2013; Sriyalatha, 2016), become members of credit unions (Račkauskas, Liesionis, 2013; Turner, 2015), intentions to take a pay day loan (Wilson et al., 2010; Bhutta et al., 2015; Barth et al., 2014). Over the last few years research on alternative credit providers and their advantages over traditional credit providers is gaining interest as well (Bruton et al., 2015; Kim et al., 2016; Drummer et al., 2016). Depending on what credit service is chosen as the research object, two trends in the research may be identified: the impact of different demographic factors and customer characteristics on the borrowing behavior of such customers (Oosterbeer, van de Broek, 2009; Devlin, 2009; Chatterjee, 2013), and the importance of the characteristics of credit services (Liao, Cheung, 2002; Maiyaki, 2011; AlišauskaitèŠeškienè et al., 2015) for choosing the particular credit service. However, there is a lack of the complex studies which would assess overall attractiveness and usage of various credit services (rather than a single credit servise) and which would include both user characteristics and service characteristics in order to define the determinants influencing the choice of credit services. The research problem addressed in the article is about finding out the determinants that influence the choices of credit services. To explore the research problem, one segment of the credit users - university students were selected to capture high frequency users of new technologies and also to represent consumers with new (modern) behavioral patterns. Researchers often favour the student target group due to their better accessibility to questionaires. Moreover, this target group does not have subjective reasons to conceal their financial situation and future intentions, and from a psychological point of view, the students' behavior analysis also allows to predict their future habits.

The research object: the choice of credit services among students.

The aim of the research is to identify the determinants of credit services' choices among students. Specifically, the article explores what is the influence of socio-demografic and psychological characteristics of a student (as prospective use 
of credit services) on his/her attitude towards the characteristics of a credit service while making a choice of the credit service.

\section{Theoretical aspects of the behavior of credit service users}

The financial behavior associated with credit taking decisions is researched from different viewpoints. There are two main research directions in this field: one focusing on the impact of personal characteristics of the credit service user on his/ hers borrowing decisions (Devlin, 2009; Disney, Gathergood, 2013; Račkauskas, Liesionis, 2013); another focusing on the certain characteristics of credit services and their providers that are important in the decision-making process of borrowers (Sriyalatha, 2016; Alqasa, Balhareth, 2015; Liao, Cheung, 2002; Yang, Lee, 2016; Lajuni et al., 2017).

\section{Personal characteristics of the borrower as determinants of borrowing behavior}

Customer characteristics is one of the areas of research that is important both in the general sense of financial behavior and in the context of borrowing decision making (Zuroni, Lim, 2012; Sriyalathe, 2016). The following is a summary of earlier research that distinguishes what characteristics of credit service customer are most commonly included in this area of research.

Disposable income. Credit services customers can be characterized by income differentiation (Disney, Gathergood, 2013). In the literature, the prevailing view is that credits are opted for by people with lower incomes (Oosterbeer, van de
Broek, 2009; Sriyalatha, 2016). It is noted that consumers of different credit services have different income levels. Credit-union customers have been found to belong to the middle-class (Chilingerian, 2012) or to have monthly disposable income higher than average (Devlin, 2009; McKillop, Wilson, 2011; Račkauskas, Liesionis, 2013). The studies of J. F. Devlin (2009) and B. J. Wilson et al. (2010) show that pay-day loans consumers have lowincome. Meanwhile, J. Lee (2003) study results show that income distribution is not a statistically significant factor in assessing intent to borrow online.

Age. According to a study conducted by $\mathrm{H}$. Oosterbeer and A. van de Broek (2009), a statistically significant relationship was found between the age of respondents and their intention to borrow. J. F. Devlin (2009) shows that the most active users in the credit markets are those aged 26-35. Research by A. Turner (2015), M. Račkauskas and V. Liesionis (2013) show that young people are more active in using traditional banking services. In the case of the Lithuanian academic credit union, the largest share of clients is between the ages of 31 and 45 (Račkauskas, Liesionis, 2013). S. Chatterjee (2013) observes that among pay-day loan users the majority is also 26-34-year-olds.

Education. J. F. Devlin (2009), A. Turner (2015), R. Disney and J. Gathergood (2013) found that the level of education of customer is an important factor in making borrowing decisions. Such a connection is explained by the fact that customers with higher level of education are able to make financial decisions more rationally, for example, they have an opportunity to more adequately evaluate all borrowing alternatives and conditions 
offered, and to make different borrowing decisions than customers with lower level of education. This is confirmed by S. Chatterjee's (2013) study on the use of payday loan, since it has been shown that people with lower education are more likely to use payday loans, which are often less favorable than loans from banks. According to a study by A. Turner (2015), education is not the main reason why consumers are borrowing from credit unions. However, a study by M. Račkauskas and V. Liesionis (2013) revealed that individuals with lower education are more likely to stay longer in their credit unions and keep using their services. A study by J. Lee (2003) on online borrowing has shown that better educated respondents are more likely to use alternative credit services. In assessing the distribution of users of P2P lending platforms by their level of education, D. Drummer et al. (2016) also notes that borrowing innovations are more likely to be used by persons with a higher education.

Gender. This factor is considered ambiguous in literature. J. F. Devlin (2009), $\mathrm{H}$. Oosterbeer and A. van de Broek (2009), S. Chatterjee (2013), C. Smith and G. Barboza (2013) found in their studies that there was no statistically significant difference between the borrowing behavior of men and women. However, N. Sevim et al. (2012) found that women are more likely to borrow. J. M. Hogarth and K. H. O'Donnell (1997) found that gender is a significant factor in assessing the distribution of users among financial institutions.

Financial literacy. The literature does not have a predominant view of how financial literacy affects financial and, in particular, borrowing decisions. R. Disney and J. Gathergood (2013) argue that higher financial literacy correlates with the choice of "cheaper" lending services, i.e., persons with lower financial literacy have fewer opportunities to rationally assess credit conditions, and therefore rigorously choose higher interest rates that look more attractive at the time of borrowing. However, A. Lusardi and P. Tufano (2015) argue that the concept of debt literacy, which measures the level of knowledge about the borrowing process, can be used to assess consumer behavior in the credit market. Despite the specificity of the debtliteracy factor, financial literacy is more often used in surveys (Sevim, Saylir, 2012; Disney, Gathergood, 2013; Bahovec et al. 2015). N. Sevim et al. (2012) and V. Bahovec et al. (2015) found that the level of financial literacy is a statistically significant factor affecting borrowing behavior.

Risk tolerance. H. Oosterbeer and A. van de Broek (2009) point out that the users of credit services are more tolerant to risk than people who do not borrow. Therefore, it can be argued that individuals who have a higher risk tolerance level are more likely to borrow. The results of the J. Lee (2003) study indicate that a lower customer risk aversion is positively associated with its intention to use financial technology. In a study by S. Chatterjee (2013), payday loan consumers were found to have lower risk tolerance compared to auto-loan users.

\section{Characteristics of credit service as determinants of borrowing behavior}

Another widely explored trend in research related to the consumer behavior in the lending market is the impact of characteristics of certain credit services on the choice of service or the intention to 
use a specific lending service. According to S. Haultain et al. (2010), in many cases, the approach to specific characteristics of borrowing services may be closely related to the individual's approach to borrowing in general. According to the theory of planned behavior, it can be argued that the attitude to borrowing determines individual's intention to borrow, as well as the approach to the particular characteristics of credit services is important for the intention to choose a specific lending service. The following is a summary of earlier research that distinguishes what characteristics of credit services are most commonly included in this area of research.

According to M. A. K. Sriyalath (2016), the availability of information about a credit service is a key criterion for choosing a service in the lending market. In the latter author's view, many other criteria correlate with the availability of information. A study in Sri Lanka has shown that availability of information about the service affects consumers' decision to use credit cards. It can be argued that only with sufficient information the consumer can evaluate all borrowing opportunities and, taking into account other important criteria, to make the most rational decision.

Loan delivery time. In developed society, consumers are sensitive to the speed of service delivery (Liao, Cheung, 2002). Assessing the importance of the speed of the service in the process of obtaining a loan, it can be argued that the consumer will tend to choose that credit provider and service, which will allow him to receive the required amount of money as soon as possible. This criterion may also include the duration of bureaucratic processes, the length of the application for a loan and the period of receiving final decision about the loan (Wilson et al., 2010).

User-friendliness is related to the need for technological and computerbased knowledge to take advantage of the service (Liao, Cheung, 2002). Q. Yang and Y. C. Lee (2015) note that lending services that require higher levels of computer or technological skills have a limited range of users, since some members of society do not have the necessary skills, therefore, they prefer a simpler method of lending, for example, they simply use the services of banks or credit unions in person.

Accuracy and reliability are a significant criterion for disclosing the quality of lending services. According to Z. Liao and M. T. Cheung (2002), the accuracy can be measured in terms of expectations of transaction and system errors. Meanwhile, the reliability aspect is important while lending services may involve large amounts of money as well as personal confidential data. Reliability is measured by confidentiality, transaction constraints, and security awareness. A. A. Maiyaki (2011) found that bank reputation and security of consumer personal data are among four key characteristics that determine the customers choice of a particular bank and its services. Studies by K. M. Alqasa and H. Balhareth (2015) have found that service quality has a high impact on the individual's intention to use a lending service. This feature of the credit service is closely related to customer trust. Greater general trust in financial institutions leads to a greater probability for a person to choose a bank or credit union loan (Alqasa, Balhareth, 2015). Trust is particularly important for adoption of new financial technologies, since consumers need to be assured of their security by 
starting to use them and replacing existing lending methods (Yang, Lee, 2016). Meanwhile, Turner (2015) argues that trust can be seen as an important factor, but due to consumers' attachment to the particular financial institution, it may have lower infuence on the customers choice of credit service provider.

Mobility and 24/7 availability are partly linked to the above-mentioned loan delivery characteristic. However, B. J. Wilson et al., (2010) point out that accessibility of a credit service should be understood as a "physical opportunity for consumers to get a loan anywhere and anytime." Usually, loans are granted at a branch of a bank or a credit union when a client comes and applies for a loan. This kind of service is not mobile because of two reasons: 1) bank branches are mostly located only in larger cities, making the rural population harder to access credit services of this kind, 2) banks and credit unions have limited working hours (Bhutta et al., 2015) According to this characteristic (Karlan, Zinman, 2010), payday loan providers have a competitive advantage in the credit market, since this type of credit services is readily available and this criterion can be decisive for choosing a credit service in prticular cases. However, A. A. Maiyaki (2011) argues that the accessibility of lending services and mobile banking option is not one of the determining factors influencing the choice of the credit provider.

Summarizing the analyzed research in this field, the dependent variable is most often encoded as a qualitative variable, depending on the respondent's answer, whether he/she uses or has intentions to use particular credit service, i.e. whether he/she has a credit card, or uses e-banking, or uses the $\mathrm{p} 2 \mathrm{p}$ lending platforms, etc. The importance of researched credit service characteristics for customers is most often measured using Likert's 5-point scale (Liao, Cheung, 2002, Yang, Lee, 2015, Alqasa, Balhareth, 2015, Sriyalathe, 2016). Due to the abundance of variables used, it is difficult to summarize the results of all analyzed surveys. However, it becomes clear that the research into the intention of borrowers to borrow and the choice of particular lending instrument is fragmentated and therefore there is a lack of cross-sectoral research that studies the overall intention to borrow and combine demographic factors and the impact of lending instruments' characteristics.

In recent years, financial technologies that provide alternative borrowing methods and may be called new providers of credit services competing with traditional market players (banks and credit unions) are entering the lending market. The customers intentions to borrow and to choose a particular credit service become even more crucial. The particular characteristics of a credit service may be valued differently by existing and potencial customers of a credit services market as well. The importance of the availability of information about credit service, the speed of credit delivery, accessibility of a credit service, accuracy and reliability of a credit service and credit provider may be valued differently in the changing lending marketplace.

\section{Research methods}

Research objective. There will be examined the factors which determine the attitudes of students towards the characteristics of credit services and their 
importance, which later influence decision-making related to the choice of a specific lending service.

Sampling. The target group of this research is university students in Lithuania. Student behavioral research is a common trend in research literature (Haultain et al., 2010; Ismail, 2011; Žukauskas, Žukauskiene, 2011; Sereetrakul et al., 2013; Alqasa, Balhareth, 2015; Sriyalathe, 2016). In their studies, C. Smith and G. Barboza (2013), K. M. Alqasa and H. Balhareth (2015) choose the students as the most accessible target group. W. Sereetrakul et al. (2013) notes that this target group does not have subjective reasons to conceal its financial situation and future intentions, and psychologically, students behavioral analysis allows to make insights on their future habits. According to the Department of Statistics of the Republic of Lithuania, in the 2016/2017 academic year, 29,038 students were enrolled in the Lithuanian university's bachelor and master studies.

In order to obtain representative data sample reflecting the entire population non-probabilty sample technique was applied (Kardelis, 2016). The respondents were chosen randomly, and students could be from any involved university or faculty, studying in undergraduate, postgraduate or integrated study programs. It is estimated that there is a minimum representative sample of 379 students that allows to make conclusions about the entire population.

Questionnaire. The quantitative questionnaire research method has been selected due to the limited availability of statistical data. The individual response of each respondent is of particular impor- tance in analyzing psychological behavior and other qualitative indicators. The critical drawback of the survey method is based on the assertion that respondents may provide false information in answering questions, but this study suggests that ensuring confidentiality allows respondents to answer questions accurately without distorting the data.

The questionnaire was constructed from the closed-type questions assigned to collect information on the various aspects of borrowing behavior and attitudes of Lithuanian university students. The structured questions were chosen for this research with limited answers' options by nominal, ordinal, Likert or semantic differential range. The questions and answer optitions were adapted to the target group of students. Closed-type questions were prioritized due to their better precision and higher comparability of results, which is necessary for quantitative analysis. The research questionnaire consisted of 11 questions. The first group of questions were designed to identify respondent's characteristics (such as gender, studies, financial literacy, risk tolerance and financial situation). The earlier mentioned education level factor is not included in the questionaire as all the respondents are university students and it is assumed that education level is uniform along the respondents' group. Due to the narrow distribution of respondents' age, since only students are involved in the survey, it was decided to consider the age factor as the course of current enrollment. The financial literacy factor is most often assessed on the basis of answers to certain control questions. Scientists are arguing about a fair number of questions that allow an 
objective assessment of a person's financial literacy level (Lusardi, 2006; Atkinson, Messy, 2012; Bonte, Filipiak, 2012). In this study, the financial literacy of respondents will be assessed using Lusardi methodology of 3 questions that reflect respondents' perceptions of compound interest rates, inflation and risk diversification issues. According to V. Bahovec et al. (2015), a cluster analysis of $\mathrm{K}$-averages was used to classify respondents according to their answers to financial literacy questions into three groups: high, average and low financial literacy level. For risk tolerance measurement, the subjective assessment method was used when respondents were asked to assess whether they are risktaking or not. A categorical factor is used for the assessment of the financial situation of students, since the questionnaire presents possible answers of income ranges.

Another group of questions was targeted at testing respondents' attitudes towards different characteristics of credit products. The wording of the question asks the respondents to evaluate the significance of the characteristic using the 5-point Likert scale. In order to avoid subjective conception of the lending services characteristics, respondents were provided with 17 statements that detail the availability of information about credit service, as well as reliability, price and accessibility of credit service. The statements were made at random, so that the preceding statement would not affect the assessment of another statement. The availability of information, reliability and accessibility of services questions were formulated according to Z. Liao and M. T. Cheung (2002), I. AlišauskaitèŠeškienè et al. (2015), L. M. Chuang et al. (2015) and M. A. K. Sriyalathe (2016). It is assumed that aggregated estimates of points for each statement reflecting one characteristic of the credit services determine the respondent's attitude to this particular characteristic.

The compatibility of the questionnaire was assessed using Cronbach Alpha coefficient test which allows determining the consistency of the scale. In the social research, the Cronbach Alpha coefficient should be equal to or greater than 0.6 (Kardelis, 2016). It was found that the significance of the Cronbach Alpha coefficient for the statements about lending services' characteristics was 0.816 , and therefore the questionnaire was compiled correctly. A pilot questionaire was submitted to 25 respondents in order to assess whether questions were understandable by the participants.

Timeline and distribution. The research data was collected using a survey method. The questionnaire was uploaded to a special website and the link was distributed to the target audience by e-mail, targeting social media groups and other channels. The survey was conducted over March and April in 2017.

Research method. The survey data is used to assess the impact of students' demographic characteristics on their attitude to lending services' characteristics. Statistical analysis of frequencies assesses how the attitude to information availability, service reliability, price, and service accessibility depends on the characteristics of the respondent: sex, course of enrollment (age), financial literacy level and risk tolerance level.

As the data are not normally distributed, the ANOVA method cannot be used. Therefore, the relationship between the 
student demographic factors and their attitude towards the characteristics of lending services is determined by using the dependence analysis of the attributes using the Chi-square $(\chi 2)$ test. In this stage of the research, a seperate characteristic frequency table will be created for each lending service characteristic and the value of $\chi 2$ is checked. Signs with $\chi^{2}<0.05$ are considered statistically significantly dependent.

Liminations of the reseacrh. It is important to note that there could be a chance of error in sampling as the respondents' structure could not match projected sample structure and not fully represent all students' behavioral patterns. The second limitation could be caused by the selected data collection method. As the survey method always leaves a potential misinterpretation of questions or not properly disclosed information. The third limitation is related to the choice of measurement methods of some particular factors included in the research, such as financial literacy, risk tolerance, attitudes towards different credit products' characteristics.

\section{Research results}

\section{Descriptive statistics of research data}

It can be stated that the survey data is representative as 391 students from 6 universities provided their answers. All questionnaires were filled in correctly and all answers are included in the study.

Altogether 118 men (30.18\%) and 273 women $(69.82 \%)$ participated in the study. This result can be expected given the fact that the female population at universities is higher than that of men. Students of senior courses participated more actively in the study, i.e., more than $73 \%$ of respondents are 3-4-year undergraduate and 1-2-year master students, representing various study fields. During the survey, 169 students had a constant income flow. More than half of the students (57.47\%) had disposable monthly income of up to 300 euros. Also, 15.98\% of respondents said their disposable income was higher than $€ 601$. Moreover, 37 students out of the 62 students with a monthly disposable income of over 601 euro, were graduate students. Among the respondents, risk aversion is prevalent (taking into account the subjective risk tolerance assessment). Thus, 226 respondents $(57.80 \%)$ noted that they avoid risk, while 165 respondents (42.20\%) said they were risk tollerant. Also, 194 respondents answered correctly to all 3 financial literacy questions, 125 respondents provided 2 correct answers, while the smallest percentage of respondents (72 students) answered correctly one or none of financial literacy questions.

Furtheremore, 315 of the surveyed students $(80.56 \%)$ said they had never used any lending services before. However, $38.11 \%$ think that they will have to borrow in the next 3 years.

The last part of the questionnaire was intended for the evaluation of the characteristics of credit services. The results related to the importance of service characteristics for respondents using the 5-point Likert scale are summarized in Table 1 .

All the statements were evaluated by a score summarizing all the answers of respondents and marking the importance of some particular characteristics of a 
Table 1. The results of scores for the complying statements of each credit service characteristic

\begin{tabular}{|c|c|c|c|}
\hline $\begin{array}{c}\text { Service } \\
\text { characteristics }\end{array}$ & Statement & $\begin{array}{l}\text { Statement } \\
\text { score }\end{array}$ & $\begin{array}{l}\text { Score for } \\
\text { credit service } \\
\text { characteristics }\end{array}$ \\
\hline \multirow{4}{*}{$\begin{array}{l}\text { Availability of } \\
\text { information }\end{array}$} & $\begin{array}{l}\text { It is important to me to have a possibility to call and consult the } \\
\text { specialist when making decision to borrow }\end{array}$ & 2,20 & \multirow{4}{*}{2,45} \\
\hline & $\begin{array}{l}\text { It is important to me that information on the crediting service } \\
\text { and its process is provided on the website of the credit provider }\end{array}$ & 1,96 & \\
\hline & $\begin{array}{l}\text { It is important to me to have a possibility to visit a phisical } \\
\text { office of a credit provider and get information from employees } \\
\text { directly }\end{array}$ & 2,05 & \\
\hline & $\begin{array}{l}\text { It is important to me for the service to be advertised on televi- } \\
\text { sion / radio / press }\end{array}$ & 3,59 & \\
\hline \multirow{3}{*}{ Reliability } & Ensuring confidentiality is important to me & 1,69 & \multirow{3}{*}{1,65} \\
\hline & $\begin{array}{l}\text { The security of transactions is important to me (receiving the } \\
\text { exact loan amount, paying interest to the credit provider) }\end{array}$ & 1,70 & \\
\hline & The reputation of credit provider is important to me & 1,55 & \\
\hline \multirow{4}{*}{ Price } & $\begin{array}{l}\text { It is important to me that I could borrow without any initial } \\
\text { contribution }\end{array}$ & 2,73 & \multirow{4}{*}{2,25} \\
\hline & The interest rate is important to me & 2,45 & \\
\hline & $\begin{array}{l}\text { It is important to me that I had the opportunity to change the } \\
\text { loan repayment conditions during the repayment proceess }\end{array}$ & 2,20 & \\
\hline & $\begin{array}{l}\text { It is important to me that I had the opportunity to deffer inter- } \\
\text { est payments or loan repayment }\end{array}$ & 1,62 & \\
\hline \multirow{6}{*}{$\begin{array}{l}\text { Accessibility } \\
\text { of service }\end{array}$} & $\begin{array}{l}\text { It is important to me that the process of obtaining a loan would } \\
\text { not require significant technical / computer skills }\end{array}$ & 3,52 & \multirow{6}{*}{2,72} \\
\hline & $\begin{array}{l}\text { It is important to me that I could apply for a loan at any time of } \\
\text { the day (not only during the working hours) }\end{array}$ & 2,59 & \\
\hline & $\begin{array}{l}\text { It is important to me that I had an opportunity to get a loan } \\
\text { in places other than financial institutions, such as post office, } \\
\text { shopping mall, online }\end{array}$ & 1,68 & \\
\hline & The online administration option of my loan is importat to me & 2,40 & \\
\hline & $\begin{array}{l}\text { It is important to me to have an opportunity to borrow through } \\
\text { a mobile application }\end{array}$ & 3,25 & \\
\hline & The duration of borrowing process is important to me & 2,87 & \\
\hline
\end{tabular}

Note: ${ }^{\star} 1$ - "Totaly agree”, 2 - "Agree”, 3 - "Neither agree nor disagree”, 4 - "Disagree”, 5 - "Totaly disagree”.

credit service. The scores were graded by the Likert scale. It should be noted that the higher the estimate, the statement or the characteristics of the credit service is less important, since 1 is coded as "Very important" and 5 is "Not at all important". The data in Table 1 allows to conclude that the reputation of a credit provider is valued by the respondents as the most important together with the possibility of delaying loan repayment or interest payments, access to loans from providers other than financial institutions, confidentiality of personal data and security of transactions. The least important is advertising in the media and the necessity of computer/technical skills for reaching some crediting service. 
Assessing the overall agregated scores for each characteristic of the credit services, it can be noted that the research participants have the highest need for reliability of credit service. The availability of service is the least relevant characteristics. However, it is important to mention that none of the characteristics were evaluated as totally irrelevant as the estimates below 3 indicate that the characteristics are very important or important for the rspondents.

\section{The assessment of attitudes towards characteristics of credit services according to student demographic factors}

The respondents' attitude towards the particular characteristic of lending services are reflected by the agregate scores that they provided for each given statement describing it. The 5-point Likert scale was used for the scoring. As the data is not normally distributed and the ANOVA method cannot be used, therefore, the relationship between the students' demographic factors and their attitude towards the characteristics of credit services is determined by using the attributes dependency analysis employing the
Chi-square $\left(\chi^{2}\right)$ test. In this stage of the research, a new attribute-frequency table was created for each credit service characteristic and the value of $\chi^{2}$ is checked. Table 2 presents the values of $\chi 2$ that allows to conclude about the significance of the differences in attributes. Signs with $\chi^{2}$ $<0.05$ are considered statistically significantly dependent.

As it can be seen from the data presented, most of the attributes are identified as statistically significantly independent. Consequently, only statistically significant frequency tables will be presented and discussed. The following dependencies were determined as statistically significant: 1) gender and the availability of credit services (Sig. $=0.023$ ); 2) age and availability of information about credit service (Sig $=.007) 3$ ) age and reliability of credit service ( $\mathrm{Sig}=0.032)$; 4) financial literacy level and reliability of credit service (Sig $=0.019) ; 4)$ risk tolerance level and availability of credit service (Sig. = 0.028).

Availability of information about credit service. The importance of availability of information about credit service according to the Chi-square criterion can be considered as statistically dependent only on the age of student. Yet $57.1 \%$ of students that declared these

Table 2. Results of dependency analysis among attributes (Chi-square test)

\begin{tabular}{|l|c|c|c|c|}
\hline & $\begin{array}{c}\text { Availability of } \\
\text { information }\end{array}$ & Reliability & Price & $\begin{array}{c}\text { Accessibility of } \\
\text { service }\end{array}$ \\
\hline Gender & 0,124 & 0,165 & 0,812 & $\mathbf{0 , 0 2 3}$ \\
\hline Age (year of study) & $\mathbf{0 , 0 0 7}$ & $\mathbf{0 , 0 3 2}$ & 0,127 & 0,879 \\
\hline Employement & 0,578 & 0,545 & 0,566 & 0,439 \\
\hline Financial literacy & 0,537 & $\mathbf{0 , 0 1 9}$ & 0,906 & 0,383 \\
\hline Risk tolerance & 0,949 & 0,903 & 0,681 & $\mathbf{0 , 0 2 8}$ \\
\hline
\end{tabular}


characteristics of credit service as very important were studying in the senior courses. Even though the statistically significant dependency of this credit services' characteristic on other demorgaphic factors were not found, we could track some general tendencies. Women are more likely to consider the availability of information about the credit service as more important than men. This characteristic could be more important for respondents with lower level of financial literacy or who are unemployed.

Reliability of credit service. The reliability of credit service is statistically dependent on respondent's age and level of financial literacy. The majority of MSc students involved in the study (49.6\%) rated credibility as very important. This characteristic of credit service is also of great importance for respondents with higher financial literacy. Respondents with low financial literacy have a relatively higher number of respondents who claim that this characteristic is neither significant nor irrelevant. A slightly higher proportion of women (91.2\%) said that service reliability was important or very important (men - 86.5\%). Reliability was also more important for students that are more risk averse. The results showed that respondents put relatively higher importance on this characteristic from all the analyzed set.

The price of credit service. Based on the Chi-square criterion, the importance of the price of a credit service cannot be explained by any demographic factor, but it is nevertheless noted that the cost of credit is more important for men, older and working students. Also, a higher financial literacy leads to a higher level of importance put on the price of a credit service. Such results can be explained by the fact that students with higher financial literacy are better able to assess the real cost of the service and to compare the different conditions offered by different credit providers.

Accessibility of credit service. The importance of accessibility of credit service is statistically significantly dependent on respondent's gender and level of risk tolerance. It was found that both men and women generally stated that their attitude to service availability was neutral. This answer was chosen by $61.9 \%$ of women and $49.2 \%$ of men. However, the general tendency can be seen that this characteristic is more important for men than women, as $39 \%$ of men assessed this characteristic as very important or important in comparison with $24.5 \%$ of women).

The difference between the attitudes towards accessibility of students who are risk averse and those with high risk tolerance is statistically significant. This characteristic of credit service is more important for respondents who tolerate risk. The qualitative assessment of statistically insignificant indications shows that the accessibility of the credit service is more important for older respondents, as well as unemployed respondents and respondents with lower financial literacy.

The summarized qualitative results are presented in Table 3 distinguishing which credit service characteristics are considered to be very important and completely irrelevant for respondents with different demographic features. The light grey color marks demographic factors for which the credit service 
Table 3. Summary of qualitative analysis results (\% of respondents from a particular demographic group)

\begin{tabular}{|c|c|c|c|c|c|c|c|c|c|}
\hline \multirow{2}{*}{\multicolumn{2}{|c|}{\begin{tabular}{|lr}
$\begin{array}{l}\text { Demographic } \\
\text { characteristics }\end{array}$ & $\begin{array}{l}\text { Credit service } \\
\text { characteristics }\end{array}$ \\
\end{tabular}}} & \multicolumn{2}{|c|}{$\begin{array}{c}\text { Availability of } \\
\text { information }\end{array}$} & \multicolumn{2}{|c|}{ Reliability } & \multicolumn{2}{|c|}{ Price } & \multicolumn{2}{|c|}{$\begin{array}{c}\text { Accessibility of } \\
\text { service }\end{array}$} \\
\hline & & + & - & + & - & + & - & + & - \\
\hline \multirow{2}{*}{ Gender } & Female & $44,4 \%$ & $3,7 \%$ & $91,2 \%$ & $2,2 \%$ & $59,3 \%$ & $3,0 \%$ & $24,5 \%$ & $13,6 \%$ \\
\hline & Male & $37,3 \%$ & $8,4 \%$ & $86,4 \%$ & $0,8 \%$ & $63,5 \%$ & $3,3 \%$ & $39,0 \%$ & $118 \%$ \\
\hline \multirow{3}{*}{$\begin{array}{l}\text { Age (year of } \\
\text { study) }\end{array}$} & $1-2$ year & $41,2 \%$ & $2,0 \%$ & $82,3 \%$ & $2,0 \%$ & $49,9 \%$ & $2,0 \%$ & $29,5 \%$ & $12,7 \%$ \\
\hline & 3-4 year & $50,0 \%$ & $2,4 \%$ & $95,1 \%$ & $0,6 \%$ & $64,0 \%$ & $1,2 \%$ & $30,5 \%$ & $11,0 \%$ \\
\hline & Master & $32,8 \%$ & $11,2 \%$ & $88,2 \%$ & $3,2 \%$ & $60,8 \%$ & $6,4 \%$ & $26,4 \%$ & $16,0 \%$ \\
\hline \multirow{2}{*}{ Employeement } & Unemployeed & $43,7 \%$ & $4,6 \%$ & $88,3 \%$ & $1,4 \%$ & $57,7 \%$ & $2,8 \%$ & $32,0 \%$ & $11,8 \%$ \\
\hline & Employeed & $40,2 \%$ & $5,9 \%$ & $91,7 \%$ & $2,4 \%$ & $64,5 \%$ & $3,6 \%$ & $24,9 \%$ & $14,8 \%$ \\
\hline \multirow{3}{*}{ Financial literacy } & High FR & $39,7 \%$ & $5,1 \%$ & $94,3 \%$ & $1,5 \%$ & $64,4 \%$ & $2,6 \%$ & $24,2 \%$ & $13,9 \%$ \\
\hline & Average FR & $41,1 \%$ & $4,8 \%$ & $87,3 \%$ & $1,6 \%$ & $57,2 \%$ & $4,0 \%$ & $33,0 \%$ & $12,9 \%$ \\
\hline & Low FR & $50,6 \%$ & $5,5 \%$ & $80,8 \%$ & $2,7 \%$ & $56,1 \%$ & $2,7 \%$ & $34,3 \%$ & $11,0 \%$ \\
\hline \multirow{2}{*}{ Risk tolerance } & Low & $41,6 \%$ & $4,4 \%$ & $90,7 \%$ & $1,3 \%$ & $60,6 \%$ & $3,1 \%$ & $24,4 \%$ & $15,9 \%$ \\
\hline & High & $43,0 \%$ & $6,1 \%$ & $88,5 \%$ & $2,4 \%$ & $60,6 \%$ & $3,0 \%$ & $35,1 \%$ & $9,1 \%$ \\
\hline
\end{tabular}

Note: (+) - important; (-) - not important

Dark grey color - demographic factors that have a relatively lower significance, i.e., percentage of respondents in a particular demographic group claiming that the characteristic is irrelevant or completely irrelevant.

Light grey color - demographic factors, for which the credit service characteristics are relatively more important, i.e. percentages are presented that reflect how many respondents in a particular demographic group have claimed that the characteristic is very important or important.

characteristics are relatively more important, i.e. percentages reflect how many respondents in a particular demographic group have claimed that the characteristic is very important or important. The dark grey color indicates those factors that have a relatively lower significance, i.e. percentage of respondents in a particular demographic group claiming that the characteristic is irrelevant or completely irrelevant. The results reveal that women put higher importance on the availability of information about the credit service and the reliability of the credit service. Men consider the price of the credit service and the accessibility of the credit service as more important. Respondents with higher financial literacy score focus on the reliability of the credit service and the price of the credit service.

\section{Conclusions}

Demographic factors are often identified in the scientific literature as affecting a person's intention to use credit services. The researchers often relate the choice of lending services to the approach of the borrower to the characteristics of credit services and their importance. The research in this field can be evaluated as fragmented - there is lack of a complex assessment, which would allow linking the customer intention to borrow with paricular credit services including new lending services.

The analysis of the respondents' answers revealed that the reliability of credit services is the most important for researched students. Also, an important characteristic is the cost of the service 
and the availability of information about a credit service. The least important of all the researched characteristics was the availability of the service to the user. The main conclusions about the influence of respondents' characteristics on their choices of credit services were drawn. First of all, according to the research results, it can be declared that the importance of particular characteristics of credit services has no statistically significant dependence on demographic factors of potential customers. However, qualitative data analysis revealed tendencies for women to value the availability of information about credit service and reliability of service more than men. However, men tend to value the cost of credit service and availability of credit service more than women. Given the differences in financial literacy, students with higher financial literacy rates were more likely to value the reliability and cost of a credit service much more than students with lower level of financial literacy. Respondents that have the lower level of financial literacy care more about the availability of information about the service and acceessability of a credit service (for example, 24/7). As expected, students with lower risk tolerance attach comparativelly greater importance to the reliability and costs of a credit service, while the availability of information about a credit service and accessability of a credit service is more relevant to individuals that tolerate much higher risk.

Based on the findings of the study, the importance of characteristics of the credit services identified in the research could be taken into account by credit providers, and the impact of demographic factors on borrowing and choosing a particular credit service can be tailored to specific target groups and segments as potential customers.

\section{References}

1. Ališauskaité-Šeškienė, I., Remeikienè, R., Gasparenienè, L. (2015). The Factors that Determine Physical Entities' Borrowing: Lithuanian Case // Procedia Economics and Finance. Vol. 26, pp. 616-622. doi: 10.1016/ S2212-5671(15)00798-4.

2. Alqasa, K. M., Balhareth, H (2015). The Impact of Service Quality and Cultural Beliefs on Intention to Use Financial Services: The Moderating Role of Trust // Asian Social Science, Vol. 11, No. 21. doi: 10.5539/ass.v11n21p20.

3. Atkinson, A., Messy, F. A. (2012). Measuring Financial Literacy: Results of the OECD // OECD Working Papers on Finance, Insurance and Private Pensions. No. 15. doi: 10.1787/20797117.

4. Bahovec, V., Barbic, D., Palic, I. (2015). Testing the Effects of Financial Literacy on Debt Behavior of Financial Consumers Using Multivariate Analysis Methods // Croatian Operational Research Review, CRORR. Vol. 6, pp. 361-371. doi: 10.17535/crorr.2015.0028.
5. Barth, J. R, Hilliard, J., Jahera, J. S. (2014). Banks and Payday Lenders: Friends or Foes? // International Advances in Economic Research. Vol. 21. Issue 2, pp. 139-153. doi: 10.2139/ssrn.2505036.

6. Bhutta, N., Skiba, P. N., Tobacman, J. (2015). Payday Loan Choices and Consequences // Journal of Money, Credit and Banking. Vol. 47. Issue 2-3, pp. 223-260. doi: 10.1111/jmcb.12175.

7. Bonte, W., Filipiak, U. (2012). Financial Literacy, Information Flows and Caste Affiliation: Empirical Evidence from India // Journal of Banking \& Finance. Vol. 36. Issue 12, pp. 33993414. doi: 10.1016/j.jbankfin.2012.07.028.

8. Bruton, G., Khavul, S., Siegel, D. et al. (2015). New Financial Alternatives in Seeding Enterpremeurship: Microfinance, Crowdfunding, and Peer-to-Peer Innvonations // Entrepreneurship: Theory and Practice. Vol. 39. Issue 1, pp. 9-26. doi: 10.1111/etap.12143.

9. Chatterjee, S. (2013). Borrowing Decisions of Credit Constrained Consumers and The 
Role of Financial Literacy // Economics Bulletin. Vol. 33 No. 1, pp. 179-191. Persistent link: https://EconPapers.repec.org/ RePEc:ebl:ecbull:eb-13-00039.

10. Chilingerian, N. (2012). CU Members displaying confidence in Economy // Credit Unions Time Magazine. Internet access: https://www.cutimes.com/2012/04/01/creditunion-members-displaying-confidence-inecon/?slreturn=20180620070852.

11. Chuang, L. M., Liu, C. C., Kao, H. K. (2016). The Adoption of Fintech Service: TAM perspective // International Journal of Management and Administrative Sciences. Vol. 3, No. 7, pp. 1-15.

12. Devlin, J. F. (2009). An Analysis of Influences on Total Financial Exclusion // The Service Industries Journal. Vol. 29, No. 8. pp. 1021-1036. doi: $10.1080 / 02642060902764160$.

13. Disney, R., Gathergood, J. (2013). Financial Literacy and Consumer Credit Portfolios // Journal of Banking \& Finance. No. 37, p. 2246-2254. doi: 10.1016/j.jbankfin.2013.01.013.

14. Drummer, D., Jerenz, A., Siebelt, P. et al. (2016). FinTech - Challenges and Opportunities: How digitization is transforming the financial sector. - McKinsey\&Company Working Papers. Issue: May.

15. Gasparenienė, L., Remeikienè, R., Valinskienè, R. (2015). Market Trends of Personal Borrowing by Taking Credit // Procedia - Social and Behavioral Sciences. Vol. 213, pp. 31-36. doi: 10.1016/j.sbspro.2015.11.399.

16. Haultain, S., Kemp, S., Chernyshenko, O. S. (2010). The Structure of Attitudes to Student Debt // Journal of economic Psychology. Vol. 31, Issue 3, pp. 322-330. doi: 10.1016/j. joep.2010.01.003.

17. Hogarth, J. M., O’Donnell, K. H. (1997). Being Accountable: A Descriptive Study of Unbanked Households in the U.S. // Proceedings of the Association for Financial Planning and Counseling Education. P. 58.

18. Ismail, S. (2011). Student's Attitude to Educational Loan Repayments: A Structural Modelling Approach. - Dissertation, Brunel University.

19. Kardelis, K. (2016). Mokslinių tyrimų metodologija ir metodai. Vilnius: Mokslo ir enciklopedijų leidybos centras

20. Karlan, D., Zinman, J. (2010). Expanding Credit Access: Using Randomized Supply Decisions to Estimate the Impacts // Review of Financial Studies. Vol. 23, No. 1, pp. 433-464. doi: 10.1093/rfs/hhp092.
21. Kennedy, B. P. (2013). The Theory of Planned Behavior and Financial Literacy: A Predictive Model for Credit Card Debt? - Marshall University.

22. Ketterer, J. A. (2017) Digital Finance. New Times, New Challenges, New Opportunities. - Discussion paper No. IDB-DP-501. InterAmerican Development Bank.

23. Kim, Y., Park, Y. J., Choi, J. et al. (2016). The Adoption of Mobile Payment Services for "Fintech" // International Journal of Applied Engineering Research. Vol 11, Issue 2, pp. 1058-1061.

24. Lajuni, N., Ming, W. W. P., Yacob, Y. et al. (2017). Intention to Use Islamic Banking Products and Its Determinants // International Journal of Economics and Financial Issues. No. 7(1), pp. 329-333.

25. Lee, J. (2003). Factors Affecting Intention to Use Online Financial Services. - Dissertation, The Ohio State University.

26. Liao, Z., Cheung, M. T. (2002). Internet-based E-banking and Consumer Attitudes: An Empirical Study // Information \& Management. No 39, Vol. 4, pp. 283-295. doi: 10.1016/ S0378-7206(01)00097-0.

27. Lusardi, A., Mitchell, O. (2006). Financial Literacy and Planning: Implications for Retirement Wellbeing // Pension Research Council Working Papers. No. PRC WP 20061. Internet access: http://citeseerx.ist.psu.edu/ viewdoc/summary?doi=10.1.1.74.1946.

28. Lusardi, A. (2013). Financial Literacy and Highcost Borrowing in the United States // National Bureau of Economic Research Working papers. No. 18969. doi: 10.3386/w18969.

29. Lusardi, A., Tufano, P. (2015). Debt Literacy, Financial Experiences, and over Indebtedness // Journal of Pension Economics and Finance. Vol. 14, Issue 4, pp. 332-368. doi: 10.1017/ S1474747215000232.

30. Maiyaki, A. A. (2011). Factors Determining Bank's Selecton and Preference in Nigerian Retail Banking // International Journal of Business and Management. Vol. 6, No. 1. doi: 10.5539/ ijbm.v6n1p253.

31. McKillop, D., Wilson, J. O. S. (2011). Credit Unions: A Theoretical and Empirical Overview // Financial Markets Institutions \& Instruments. No. 20(3), pp. 79-123. doi: 10.1111/j.1468-0416.2011.00166.x.

32. Oosterbeek, H., van de Broek, A. (2009). An Empirical Analysis of Borrowing Behavior of Higher Education Students in the Netherlands 
// Economics of Education Review. Vol. 28, Issue 2, pp. 170-177. doi: 10.1016/j. econedurev.2008.01.005.

33. Račkauskas, M., Liesionis, V. (2013). Kredito unijos narių finansinè elgsena atsižvelgiant $i$ jų asmenines savybes // Vadyba. Vol. 22, Issue 1, pp. 127-133.

34. Sereetrakul, W., Wongveeravuti, S., Likitapiwat, T. (2013). Gender Differences in Saving and Spending Behaviours of Thai Students // Research in Education. Vol. 90, Issue 1, pp. 68-81. doi: 10.7227/RIE.90.1.5.

35. Sevim, N., Temizel, F., Sayilir, O. (2012). The Effects of Financial Literacy on the Borrowing Behavior of Turkish Financial Consumers // International Journal of Consumer Studies. Vol. 36, Issue 5, pp. 573-579. doi: 10.1111/j.1470-6431.2012.01123.x.

36. Smith, C., Barboza, G. (2013). The Role of Trans-Generational Financial Knowledge and Self-reported Financial Literacy on Borrowing Practices and Debt Accumulation of College Students // SSRN papers. doi: 10.2139/ ssrn.2342168.

37. Sriyalatha, M. A. K. (2016). Determinants of Customers' Attitude towards Credit Card Usage: Lessons Learned from Academics in Sri Lanka
// Case Studies in Business and Management. Vol. 3, No. 2. doi: 10.5296/csbm.v3i2.9664.

38. Turner, A. (2015). What Millennials Want: The Future of Millennials in the Credit Union System. University of Wisconsin Law School.

39. Wilson, B. J., Findlay, D. W. Meehan, J. W. et al. (2010). An Experimental Analysis of the Demand for Payday Loans // The B.E. Journal of Economic Analysis \& Policy. Vol. 10, Issue 1. doi: 10.2202/1935-1682.2563.

40. Yang, Q., Lee, Y. C. (2016). Critical Factors of the Lending Intention of Online P2P: Moderating Role of Perceived Benefit / In The 18th Annual International Conference. doi: $10.1145 / 2971603.2971618$.

41. Zuroni, M. J., Lim, Y, L. (2012). Personal Financial Knowledge and Attitude towards Credit Card Practices among Working Adults in Malaysia // International Journal of Business and Social Science. Vol. 3, No.7, pp. 176-185.

42. Žukauskas, Š., Žukauskienè, R. (2012). Studentų nuostatos skolinimosi atžvilgiu ir jų skolinimosi elgesys // Socialinis darbas. No. 11(1), p. 209-220.

The paper submitted: May 7, 2018 Prepared for publication: June 29, 2018

\section{Gintarè BARTKEVIČIŪTĖ, Asta GAIGALIENĖ, Renata LEGENZOVA STUDENTỤ KREDITAVIMO PASLAUGỤ PASIRINKIMO VEIKSNIỤ VERTINIMAS}

\section{S a n t r a u k a}

Kreditavimo rinka yra viena iš sričių, kuri susiduria su naujais pokyčiais. I šią rinką kaip ir ị visą finansų sektorių žengia naujos technologijos. Šiuolaikinis klientas yra pripratęs prie skaitmeninių erdvių (pvz., Google, Amazon, Facebook, eBay), todèl jis tikisi savo turimą patirtị patenkinti ir finansinių paslaugų rinkoje. Toks neapibrěžtumas, dinamiškai veikiantis kreditavimo rinką tiek iš tiekejjų, tiek veikiantis kreditavimo rinkos vartotojų finansinę elgseną. Kyla klausimų, kaip tradiciniai kreditavimo paslaugų tiekejjai reaguoja ị naujus kreditavimo rinkos modelius ir didejanti konkurencingumą, kaip keičiasi vartotojų prioritetai ir poreikis kintamoje kreditavimo rinkos aplinkoje. Išmatavus, kaip besiskolinančiojo demografinès charakteristikos, tokios kaip, lytis, amžius, išsilavinimas, finansinis raštingumas ir disponuojamos pajamos ittakoja jo požiūrị i tam tikras kreditavimo produktų savybes (informacijos prieinamumą, transakcijų greitị, patogumą, tikslumą, patikimumą ir mobilumą), galima atskleisti, kas lemia konkrečios kreditavimo paslaugos pasirinkimą.

Kauno miesto studentų kreditavimo paslaugos pasirinkimą lemiančių veiksnių vertinimo metodika buvo sudaryta atsižvelgiant ị kitų tyrèjų taikomų metodų praktiką. Duomenims rinkti pasirinktas apklausos metodas, platinant anketą naudojantis Kauno miesto universitetų vidiniais tinklais ir socialinių tinklų grupemis. Studentai kaip tikslinè tyrimo grupé pasirinkta dèl jų prieinamumo. Be to, 
ši tikslinė grupė neturi subjektyvių priežasčių nuslèpti savo finansinę padètị ir ateities ketinimus, o psichologiniu aspektu, remiantis studentų elgsenos analize, galima spręsti ir apie jų būsimus ịpročius. Remiantis kitų autorių tyrimo metodikų analize, pasirinkti uždarojo tipo demografiniai klausimai, finansiniam raštingumui vertinti taikyti A. Lusardi finansinio raštingumo klausimai, požiūris i kreditavimo paslaugų charakteristikas buvo vertinamas atsižvelgiant ị pateiktų teiginių vertinimą naudojant 5 balų Likerto skalę. Taikant parengtą metodiką, atliktas Kauno miesto studentų kreditavimo paslaugos pasirinkimą lemiančių veiksnių tyrimas.

Bendrai vertinant respondentu požiūrị i analizuotas kreditavimo paslaugų charakteristikas, studentams svarbiausias kreditavimo paslaugos patikimumas. Taip pat svarbi charakteristika yra paslaugos kaina ir informacijos prieinamumas. Mažiausiai svarbi iš visų charakteristikų buvo paslaugos prieinamumas vartotojui. Remiantis požiūrio ị kreditavimo paslaugų charakteristikas ir demografinių veiksnių bei kreditavimo paslaugos pasirinkimo analize, galima daryti keletą išvadų. Pirma, remiantis tyrimo rezultatais, galima teigti, kad statistiniu požiūriu demografiniai veiksniai neturi statistiškai reikšmingo poveikio jų požiūriui ì kreditavimo paslaugų charakteristikų svarbą. Vis delto kokybinė duomenų analizè atskleide tendencijas, jog moterims svarbesnis informacijos prieinamumas apie kreditavimo paslaugą ir paslaugos patikimumas, vyrams - paslaugos kaina ir paslaugos prieinamumas. Atsižvelgiant ị finansinio raštingumo skirtumus aišku, kad aukštesniu finansiniu raštingumu pasižymintys studentai labiau vertina kreditavimo paslaugos patikimumą ir kainą, o žemo finansinio raštingumo studentams svarbus informacijos ir pačios paslaugos prieinamumas. Kaip buvo galima tikètis, vengiantys rizikos studentai didelę svarbą skiria paslaugos patikimumui ir kainai, o rizikos nebijantiems studentams aktualesnis yra informacijos ir paslaugos prieinamumas.

Demografinių veiksnių poveikis ketinimui skolintis ir kreditavimo paslaugos pasirinkimui gali būti taikomas orientuojantis $\mathfrak{i}$ tam tikras tikslines grupes ir segmentus kaip i t potencialius kreditavimo paslaugu vartotojus. Interpretuojant tyrimo rezultatus, būtina atsižvelgti ị kai kuriuos apribojimus: tikslinès grupès, kintamųjų bei tyrimo metodų pasirinkimo alternatyvos. 